\title{
The Impact of Collaborative Writing on the Writing Fluency of Iranian EFL Learners
}

\author{
Reza Biria \\ Department of English, Khorasgan (Isfahan) branch, Islamic Azad University, Isfahan, Iran \\ Sahar Jafari \\ Department of English, Khorasgan (Isfahan) branch, Islamic Azad University, Isfahan, Iran
}

\begin{abstract}
Writing is no longer an individual activity but an interactive process through which social abilities of the learners are reinforced. To promote interaction in the writing class, collaboration has been suggested to be advantageous. The present study aimed to examine the impact of practicing in pairs on the writing fluency of Iranian EFL learners. To this end, an OPT test was administered to female EFL learners according to which 90 homogenous learners at an intermediate level comprised the research sample. Afterwards, the participants were randomly divided into two groups including a control group of 30 students, each producing a written text individually and an experimental group of 60 learners working in pairs. Since each pair produced a single text, the numbers of texts rather than the number of participants was considered. In order to compare the data collected from two groups, a $t$ - test was used. The results obtained from the essays written in the first session of the writing phase revealed that pairs produced less fluent texts than the individual writers. More specifically, the average number of words, T-units, and clauses in individual essays was less than that of pairs. The essays written in the last session revealed that there was a considerable improvement in the use of T-units and clauses produced by pairs; however, the fluency of the written texts was not noticeably significant in comparison with the fluency of essays produced by the individuals. The findings also revealed that practicing in pairs did improve the overall quality of the learners' writing productions even though the fluency of written texts did not change significantly.
\end{abstract}

Index Terms - collaboration in writing, individual and pair work, fluency

\section{INTRODUCTION}

The ability to write effectively and fluently in English is becoming increasingly important in today's modern world, since communication through language has become more and more essential. Writing is known as an important skill for multifarious reasons in education and business. In fact, it plays a significant role in personal and professional life. Consequently, it has become one of the major requirements in English for General Purposes (EGP) as well as English for Academic Purposes (EAP) syllabi. Evidently, the pedagogical purposes of writing range from improving, training, and practicing language in the early stages of learning to communicating fluently and accurately at intermediate and more advanced levels (Raimes, 1987).

Indubitably, writing is a complicated process through which ideas are created and expressed. Learning to write in a foreign language is even harder and it takes a considerable amount of time and effort to write skillfully. To become a skillful writer, the role of English writing instruction in foreign language education is quite prominent (Weigle, 2002). Admittedly, composing an accurate and fluent paragraph is by no means an easy task. Since learning to write is an inseparable part of language learning without which effective acquisition cannot be obtained, writing has been drawing more and more attention in language teaching and learning. In fact, writing is mostly a hard-laden task and skill for both native and non-native speakers, Iranian EFL learners being no exception. Over the last decade, research on writing has received a lot of ink in the review of the literature and it has been regarded as one of the most important communicative skills in English language teaching (see Hayes \& Flower, 1986; Sharples, Goodlet, \& Pymberton, 1989).

Over time, the interest in a more communicative approach to language teaching has resulted in the growth of pair work in second language contexts (see Hawkey, 2004). This provides language learners with opportunities to interact in collaborative situations, in which two or more learners do activities together. For a situation to be collaborative, the pairs should be more or less at the same level. According to Roschelle and Teasley (1995), collaboration is a coordinated, synchronous activity that results from a continued endeavor attempt to build and maintain a shared conception of a problem. It has been said that students can learn best in a more learner-centered, collaborative learning context compared with individualistic and competitive learning settings (D. W. Johnson \& R. T. Johnson, 1994). Learners participate actively in a collaborative learning context and construct their linguistic knowledge through interacting with other learners. AS such, Boud (2001) has introduced the term peer learning as an effective way for pairs to learn from and with each other.

Although writing is generally considered an individual activity through which ideas are transmitted from an addressor to an addressee, collaboration in writing has been drawing an increasing attention in language teaching and 
assessment (e.g., DiCamilla \& Anton, 1997; Storch, 2005; Swain \& Lapkin, 1998). Collaborative writing, which is maximizing learners' engagement and involvement in language learning practices, has turned into a value-laden, purposeful, and communicative objective. This collaboration provides the students with opportunities to interact and challenge their language knowledge in a more effective learning environment (J. Willis, 1996). However, collaboration makes the writing task more difficult compared to individual writing. To reduce such complexity, the present study makes use of pair writing in which only two students collaborate and interact to create a composition.

Topping (2001) defines paired writing as a structured system for effective learning in writing. Since the paired or group approach is potentially a viable alternative which addresses some of the concerns surrounding the more traditional approaches, the purpose of this study is to investigate how learners working together perform in a writing task. Therefore, the goal was to collect a sample of Iranian EFL learners writing at an intermediate level working in pairs and then compare them with another writing sample of EFL learners working individually. The basic assumption behind the research was to find out the effect of collaboration on the writing fluency. This has been previously done by Wigglesworth and Storch (2009) on EFL advanced-level learners but the writers focused on collaboration in an assessment context. As a result, the present study aimed to investigate whether collaboration between members of a pair helps them to write more fluent texts through interacting, giving and receiving feedback from each other. Similarly, the current study also tried to examine the influence of collaboration and pair working for duration of seven sessions to compare the degree of improvement in the writing fluency of text written individually or in pairs.

\section{LITERATURE REVIEW}

Writing as the visual channel and the productive mode of language is a vital skill for the L2 learners to develop their language knowledge and the teaching of this skill has become central in second language classrooms (Hyland, 2003). Writing, like listening, is often slighted in language classes. Especially because of the powerful influence of audio-lingual method in ELT, the oral skills have received major attention and writing has been considered less important (Matsuda, 2003). This view toward writing makes speaking the focus of language teaching in the classroom. However, White (1981, as cited in Nunan, 1989) suggests that writing should be taught separately from speaking in L2 learning.

Thus writing, as a way of expressing ideas, thinking, and learning content (J. Foster, 2008), must be regarded as an essential tool for language learning as well as communication (Tynjala, Mason, \& Lonka, 2001; Weigle, 2002). Hudelson (1988) states that L2 learners can learn how the target language works through producing language output. According to Hinkel and Fotos (2002), the role of language output in L2 learning is not less than language input because one has to be understood, as well as to be able to understand while communicating.

Along with the shift from the teacher-centered classroom to the student-centered acquisition of communicative competence, communicative approaches encourage the language students to learn the second language through contextualized and meaningful communication. Collaborative learning as a system of concrete teaching and learning techniques underlying the communicative language teaching emphasizes active interaction between students with different skills and background knowledge (Tsai, 1998). Collaborative learning is a situation in which two or more people interact with each other to trigger learning mechanisms (Dillenbourg, 1999).

In the same vein, Social constructionists claim that knowledge is negotiated and best acquired through interaction (Kurt \& Atay, 2007). One of the most well-known theories of interaction is Vygotsky's Zone of Proximal Development (ZPD) which refers to the discrepancy between the student's actual developmental level and potential or proximal level (Vygotsky, 1978).

Collaborative learning focusing the active role of students in the class has owed much credit to constructivism. The main focus of constructivism has been student-centered learning (Cheek, 1992; Yager, 1991). Constructivism embraces Vygotsky's perspective regarding social interaction as well as Piaget's approach to learning in which students play an active role to learn on their own. It is evident that L2 learners take accountability for their own learning, especially when they contribute to collaborative language output activities. Tsui (1995) defines SLA as:

Input refers to the language used by the teacher, output refers to language produced by learners and interaction refers to the interrelationship between input and output with no assumption of a linear cause and effect relationship between the two. (p. 121)

Since a great deal of attention has been paid to input and interaction in SLA (Gass, 1997), researchers have perceived that L2 learners should be also placed in situations of producing target language (see Gass \& Selinker, 2008, for a review of input, interaction, and output research). Swain (2005) states that learners' speaking or writing facilitates language learning when engaging in collaborative learning activities. Participants make use of problem-solving dialogue to solve their linguistic problems regarding the task. Furthermore, collaborative dialogue forms an important part of peer interaction.

A great number of studies in L2 have established that interaction enhances the collaborative learning experience of learners (Doughty \& Long, 2003; Gass \& Mackey, 2006; Gass \& Selinker, 2008). It is evident that learning occurs when students participate actively in collaborative activities. Along with the shift from the teacher-centered to learnercentered classrooms in CLT, group work has applied to learning contexts with the aim of intensifying communication and interaction (Sullivan, 2000). With the emerging of TBLT, group work emphasis on peer interaction has resulted in 
more negotiation for meaning (Pica, Holliday, Lewis, \& Morgenthaler, 1989). Ohta (2001) reported that peer interaction in a classroom corpus of adults learning Japanese increased their accuracy due to peer feedback and peer correction.

Morris (2008) points out that based on ZPD, peer feedback can help the learner to move from an actual level to a potential level. Peer feedback provides opportunities for the learners to negotiate meaning, to give comments and suggestions, and to make corrections (Jiao, 2007; Kamimura, 2006; Y. Zeng, 2006) so that they can find their strengths and weaknesses (Hyland, 2003; Spear, 1988; Williams, 1957). Peer feedback requires collaborative dialogue in which two parties negotiate meaning to foster language learning (Rollinson, 2005). Peer learning is a two-way reciprocal activity in which peers of the same level learn from and with each other (Boud, 2001). Since learners in peer collaboration follow a single goal, they share their cognitive resources, modifying solutions, and make joint decisions.

Although classroom peer interaction may not always result in peer learning (Kumpulainen \& Wray, 2002), more recent studies on peer-peer interaction have shown that it facilitates both peer and language learning (Lantolf, 2000). Swain and Lapkin (1998) examined peer learning in a French immersion classroom through applying a story construction task. They found that learners' accuracy was developed because of peer-peer interaction. In an examination of negotiation for meaning and correction feedback, Oliver (2002) found that peer interaction among 5- to 7-year-old L2 children could lead to language learning improvement. Pinter $(2005,2007)$ also examined 10 year-old Hungarian EFL children who benefited from peer-peer interaction and developed their social and independent skills. There is no doubt that peer interaction enhances social relationships as well as linguistic knowledge. On the other hand, peer feedback increases learners' motivation toward language learning because they feel more confident and less anxious (Tapping as cited by Kurt \& Atay, 2007).

Applying pair work to classroom context is more practical than group work since two students can learn to work effectively on activities and they can more easily come to an agreement with each other. It is obvious that pair work offers language learners with more chances to use the language. In a study on pair work activities, Macaro (1997) notified that pair interaction promoted L2 use in a two-way information exchange in contrast to a large group exchange. Storch and Wigglesworth (2007) also reported that learners working in pairs outperformed those working individually.

Cooper (1986) expresses that writing is not only a cognitive activity but a social activity which requires L2 students to interact and discuss ideas in pairs or small groups. Since L2 writing is an invaluable process and product, requiring social exchange of meaning, there is a need to find out the importance of collaboration in L2 learning.

In 2000s, researchers like Y. Zeng (2006), Kamimura (2006), Jiao (2007), and Hirose (2009) studied the influence of peer feedback in L2 writing. They stated that peer feedback had positive impact on students' writing. Although Hong (2006) found that students' attitude toward peer feedback activity in L2 was negative, Jacobs, Curtis, Braine, and Huang (1998) believed that students usually accept peer feedback in writing because feedback which is given by peers makes them feel more comfortable and confident in the writing learning environment. Rollinson (2005) mentions that peer feedback in ESL writing is recently used in learning context because of its social, cognitive, affective and methodological advantages. In contrast to teacher feedback which is product-oriented occurring at the end of the task (Lee, 2009), peer feedback is given during the task as a process, so it is more conductive and practical.

It is clearly observed that the role of peer interaction, peer feedback and socialization is important in learning language skills, more specifically writing skill. All in all, it is essential for the teachers to notice the usefulness of letting students to assist with each other in improving their language knowledge.

\section{STATEMENT OF The PRoblem}

Although the role of writing in language learning, if not more, is not less than the role of the other three language skills, it has long been ignored. Compared with the other three language skills, writing seems to be too difficult and time-consuming to teach, so little attention has been given to teach and practice writing in the class (D. Zeng, 2005). Students need enough knowledge to create and generate ideas in order to write a composition. In Iranian educational system even private language institutes, students receive little practice in writing in English. Due to students' limited proficiency, time limitation, and poor motivation, writing still remains a big hurdle. Considering learners are always hesitant to make grammatical mistakes, Al-Jarf (2007) found that peer support and feedback could help the learners to reduce such stress and improve their language knowledge as well.

\section{RESEARCH QUESTIONS AND HYPOTHESES}

The purpose of this study is to investigate the utility of collaborative writing, more specifically pair writing and its effect on the writing performance of Iranian EFL learners at an intermediate proficiency level. The main focus is the students' writing development in the case of fluency. To this end, this study addresses the following research questions.

1. Is there any difference between the degree of fluency of the essays produced by Iranian intermediate EFL learners working in pairs and those of learners working individually?

2. Does pair work influence the degree of improvement in fluency of the writing tasks?

Based on these research questions, the following null hypotheses were designed:

$\boldsymbol{H}_{01}$ : There is no difference between the degree of fluency of the essays produced by Iranian intermediate EFL learners working in pairs and those of learners working individually. 
$\boldsymbol{H}_{02}$ : Pair work does not influence the degree of improvement in fluency of the writing tasks.

\section{METHOD}

\section{A. Participants}

The participants of the present study were selected from the population of Iranian EFL students studying English in one of the institutes in Isfahan (Iran). An OPT test was administered to choose 90 participants with an intermediate level of proficiency. The reason for selecting intermediate students is that they were required to write essays of 250 words and it is believed that students of elementary with low level of L2 proficiency cannot write scripts with significant difference. On the other hand, advanced students are so developed that may not provide a clear picture of the effect of pair versus individual writing. They were all native speakers of Persian who learned English as a foreign language. This study was carried out in summer 2010 and conducted with Iranian female English learners only whose age range was from 18 to 30 . Their average age was 24 years.

The sample population was divided into two groups; namely, control and experimental. From the 90 intermediate learners selected as the result of proficiency test, 30 were randomly assigned to the control group and 60 served as the experimental group. The reason why the number of the participants in the experimental group was twice that of the control group was because the participants in the experimental group were required to write paired assignments; as a consequence, the number of writings rather than of the participants was regarded as the accessible samples.

\section{B. Design}

An OPT test was utilized for assigning the students randomly to control and experimental groups. All participants were then taught how to develop an essay through an instruction phase during which they were asked to complete, seven writing tasks.

\section{Material}

This study enlisted two kinds of materials. First, an OPT (Oxford Placement Test) test was administered to choose 90 EFL learners at an intermediate level of proficiency. The language proficiency test consisted of 100 listening and 100 grammar test items. The subjects were chosen on the basis of their scores on the OPT test, that is, those participants who scored 120-149 for intermediate level. Second, seven writing tasks were completed by the learners within seven sessions. Afterwards, 60 written texts, 30 of which produced by 30 individuals and another 30 by 60 students working in pairs in the first session as well as 60 essays of the last session were manually typed into a computer. The AntConc 3.2.1 w software was employed to count the number of words.

\section{Procedure}

This study consisted of two phases, an instruction phase and a writing phase respectively. In the instruction phase which lasted for seven sessions, the objective was to provide all the participants with somehow the same background knowledge about paragraph development and essay writing. Afterwards, the two samples were randomly assigned to the control and experimental groups.

The control group consisted of 30 learners who were asked to write essays individually. However, the 60 students of the experimental group completed the writing tasks in pairs. Since each pair was writing one text, 30 texts were produced by 60 learners in each session. The writing phase also took seven sessions, in which different topics of general interest were given to both groups. What the learners were asked to write in each session was an essay of about 250 words under time limitation. According to Storch (2005), pairs need more time to complete tasks; as a result, the pairs were given 90 minutes each session to write an essay while the individuals were given 60 minutes. At the end of the sessions, the first and the last essays were examined in terms of fluency.

\section{RESULTS}

\section{A. Null Hypothesis/ $\boldsymbol{H}_{01}$}

$\boldsymbol{H}_{01}$ : There is no difference between the degree of fluency of the essays produced by Iranian intermediate EFL learners working in pairs and those of learners working individually. Fluency of essays written by individuals was compared with that of essays produced by pairs through measuring the average number of words, T-units, and clauses per text. The following tables show the results of the comparison for the words, T-units, and clauses as well as the fluency.

\section{First Session Essays}

Table I incorporates the descriptive statistics such as mean, standard deviation, and standard error of the means regarding the essays written by all participants in the first session of writing phase. 
TABLE I.

GROUP STATISTICS FOR SUB-MEASURES OF FLUENCY IN THE FIRST SESSION ESSAYS

\begin{tabular}{|ll|l|l|l|l|}
\hline & $\mathrm{X} 7$ & $N$ & Mean & Std. Deviation & Std. Error Mean \\
\hline Words & Individual essays & 30 & $\mathbf{2 5 7 . 1 0}$ & 27.174 & 24.972 \\
& Pair essays & 30 & $\mathbf{2 4 9 . 9 0}$ & 24.972 & 4.559 \\
\hline \multirow{2}{*}{ T-units } & Individual essays & 30 & $\mathbf{1 6 . 5 3}$ & 3.839 & .701 \\
& Pair essays & 30 & $\mathbf{1 7 . 1 0}$ & 3.078 & .562 \\
\hline Clauses & Individual essays & 30 & $\mathbf{2 4 . 0 0}$ & 3.206 & .585 \\
& Pair essays & 30 & $\mathbf{2 4 . 7 0}$ & 3.261 & .595 \\
\hline
\end{tabular}

TABLE II.

INDEPENDENT SAMPES T-TESTS OF SUB-MEASURES OF FLUENCY

\begin{tabular}{|c|c|c|c|c|c|c|c|c|c|}
\hline & \multicolumn{2}{|c|}{$\begin{array}{l}\text { Levene's Test for } \\
\text { Equality of Variances }\end{array}$} & \multicolumn{7}{|c|}{$t$ test for Equality of Means } \\
\hline & \multirow[t]{3}{*}{$F$} & \multirow[t]{3}{*}{ Sig. } & \multirow[t]{3}{*}{$t$} & \multirow[t]{3}{*}{$d f$} & \multirow{3}{*}{$\begin{array}{l}\text { Sig. } \\
\text { (2-tailed) }\end{array}$} & \multirow{3}{*}{$\begin{array}{l}\text { Mean } \\
\text { Difference }\end{array}$} & \multirow{3}{*}{$\begin{array}{l}\text { Std. Error } \\
\text { Difference }\end{array}$} & \multirow{2}{*}{\multicolumn{2}{|c|}{$\begin{array}{l}\text { 95\% Confidence Interval of } \\
\text { the Difference }\end{array}$}} \\
\hline & & & & & & & & & \\
\hline & & & & & & & & Lower & Upper \\
\hline Words & 1.066 & .306 & 1.069 & 58 & .290 & 7.200 & 6.738 & -6.288 & 20.688 \\
\hline T-units & 2.073 & .155 & -.631 & 58 & .531 & -.567 & .898 & -2.365 & 1.232 \\
\hline Clauses & .069 & .794 & -.839 & 58 & .405 & -.700 & .835 & -2.371 & .971 \\
\hline
\end{tabular}

Note. Equal variances assumed

Since the two means obtained from two independent groups of students were compared, Independent Samples $t$ - test was used for analyzing the data. Table II, by contrast, shows the results of the Independent Samples $t$ test according to the means of words, T-units, and clauses for individual and pair essays. For words, the level of significance was 0.290 (bolded in Table II, under [Sig/2-tailed] column); the difference between the two groups was not significant. It means that there is no significant difference between individual and pair essays regarding the average number of words in the first session. The $p$-value for T-units $(p=0.531)$ was greater than the selected significance level of .05 ; therefore, the difference in the means of the two groups was not significant. The same result was obtained for clauses. As can be seen, the $p$-value for clauses was 0.405 and thus, the difference between the two means was not statistically significant at the $5 \%$ level of significance.

TABLE III

GROUP STATISTICS FOR TEXT FLUENCY

\begin{tabular}{|ll|l|l|l|l|}
\hline & $\mathrm{x} 7$ & $N$ & Mean & Std. Deviation & Std. Error Mean \\
\hline Fluency & Individual essays & 30 & $\mathbf{1 0 2 . 1 0 0 5}$ & 11.61427 & 2.12047 \\
& Pair essays & 30 & $\mathbf{1 0 0 . 0 1 8 8}$ & 10.66587 & 1.94731 \\
\hline
\end{tabular}

Table III illustrates the descriptive statistics of fluency as a single measure for the two groups. As can be seen, the difference in the means is not significant.

TABLE IV.

INDEPENDENT SAMPLES T-TEST OF FLUENCY BY PAIRS AND INDIVIDUALS

\begin{tabular}{|c|c|c|c|c|c|c|c|c|c|}
\hline & \multicolumn{2}{|c|}{$\begin{array}{l}\text { Levene's Test for } \\
\text { Equality of Variances }\end{array}$} & \multicolumn{7}{|c|}{ t-test for Equality of Means } \\
\hline & \multirow[b]{3}{*}{$F$} & \multirow[b]{3}{*}{ Sig. } & \multirow[b]{3}{*}{$t$} & \multirow[b]{3}{*}{$d f$} & \multirow{3}{*}{$\frac{\text { Sig. }}{\text { (2-tailed) }}$} & \multirow{3}{*}{$\begin{array}{l}\text { Mean } \\
\text { Difference }\end{array}$} & \multirow{3}{*}{$\begin{array}{l}\text { Std. Error } \\
\text { Difference }\end{array}$} & \multirow{2}{*}{\multicolumn{2}{|c|}{$\begin{array}{l}95 \% \text { Confidence Interval of } \\
\text { the Difference }\end{array}$}} \\
\hline & & & & & & & & & \\
\hline & & & & & & & & Lower & Upper \\
\hline Fluency & .845 & .362 & .723 & 58 & .473 & 2.08171 & 2.87896 & -3.68115 & 7.84457 \\
\hline
\end{tabular}

Table IV reveals the results of Independent Samples $t$ test based on the mean of fluency in individual and pair essays written during the first session. Considering significance value $p<.05$, the difference between the mean of fluency in the two groups is not significant $(p=0.473)$.

\section{Last Session Essays}

The following tables express the results obtained from the analysis of essays produced by two groups of individuals and pairs in the last session of writing phase.

TABLE V.

GROUP STATISTICS FOR SUB-MEASURS OF FLUENCY IN THE LAST SESSION ESSAYS

\begin{tabular}{|ll|l|l|l|l|}
\hline & $\mathrm{X} 7$ & $N$ & Mean & Std. Deviation & Std. Error Mean \\
\hline Words & Individual essays & 30 & $\mathbf{2 9 4 . 2 3}$ & 32.149 & 5.870 \\
& Pair essays & 30 & $\mathbf{2 8 9 . 4 7}$ & 31.075 & 5.673 \\
\hline T-units & Individual essays & 30 & $\mathbf{2 0 . 5 0}$ & 2.360 & .431 \\
& Pair essays & 30 & $\mathbf{2 2 . 0 0}$ & 2.901 & .530 \\
\hline Clauses & Individual essays & 30 & $\mathbf{3 1 . 0 0}$ & 3.543 & .647 \\
& Pair essays & 30 & $\mathbf{3 7 . 9 0}$ & 3.458 & .631 \\
\hline
\end{tabular}


Table V shows descriptive statistics for the two groups. Measures of fluency including words, T-units, and clauses were analyzed separately. Although the mean score of words in individual essays was higher than that of words in pair essays, the mean scores for T-units and clauses were higher in pair essays.

TABLE VI

INDEPENDENT SAMPLES T-TEST OF SUB-MEASURES OF FLUENCY

\begin{tabular}{|c|c|c|c|c|c|c|c|c|c|}
\hline & \multicolumn{2}{|c|}{$\begin{array}{l}\text { Levene's Test for } \\
\text { Equality of Variances }\end{array}$} & \multicolumn{7}{|c|}{$t$ test for Equality of Means } \\
\hline & \multirow{3}{*}{$F$} & \multirow{3}{*}{ Sig. } & \multirow{3}{*}{$t$} & \multirow{3}{*}{$d f$} & \multirow{3}{*}{$\begin{array}{l}\text { Sig. } \\
\text { (2-tailed) }\end{array}$} & \multirow{3}{*}{$\begin{array}{l}\text { Mean } \\
\text { Difference }\end{array}$} & \multirow{3}{*}{$\begin{array}{l}\text { Std. Error } \\
\text { Difference }\end{array}$} & \multirow{2}{*}{\multicolumn{2}{|c|}{$\begin{array}{l}95 \% \text { Confidence Interval } \\
\text { of the Difference }\end{array}$}} \\
\hline & & & & & & & & & \\
\hline & & & & & & & & Lower & Upper \\
\hline Words & .009 & .926 & .584 & 58 & .562 & 4.767 & 8.163 & -11.574 & 21.107 \\
\hline T-units & .980 & .326 & -2.197 & 58 & .032 & -1.500 & .683 & -2.867 & -.133 \\
\hline Clauses & .005 & .941 & -7.634 & 58 & .000 & -6.900 & .904 & -8.709 & -5.091 \\
\hline
\end{tabular}

Table VI reveals the results of the Independent Samples $t$ test which was done on both groups according to the mean of words, T-units, and clauses. Considering significance value $p<.05$, there was no significant difference between the mean of words in essays written by individuals and those written by pairs. The $p$-value for T-units equals 0.032 which is less than the significance level of .05. It can be concluded that there is a significant difference between the mean of Tunits in individual and pair essays. For clauses, the $p$-value is 0.000 which shows clauses were used significantly more in pair essays than in individual essays. As a whole, the average number of T-units and clauses for pairs were higher than those of the individuals.

TABLE VII

GROUP STATISTICS FOR TEXT FLUENCY

\begin{tabular}{|ll|l|l|l|l|}
\hline \multicolumn{2}{|c|}{$\mathrm{x} 7$} & $N$ & Mean & Std. Deviation & Std. Error Mean \\
\hline Fluency & Individual essays & 30 & $\mathbf{1 1 5 . 2 4 4 4}$ & 12.38771 & 2.26168 \\
& Pair essays & 30 & $\mathbf{1 1 6 . 4 5 5 6}$ & 12.24729 & 2.23604 \\
\hline
\end{tabular}

The descriptive statistics of fluency have been shown in Table VII. Looking at fluency as a single measure, the difference between the two means is not significant.

TABLE VIII.

INDEPENDENT SAMPLES T-TEST FOR FLUENCY BY PAIRS AND INDIVIDUALS

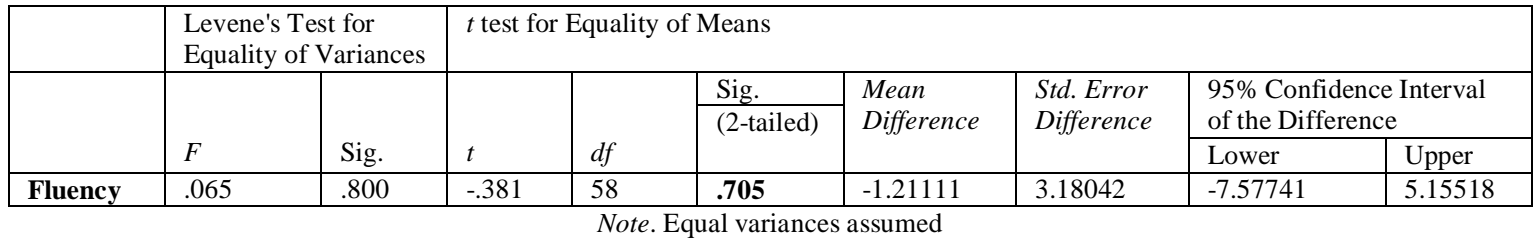

Table VIII shows the results of the Independent Samples $t$ test according to the mean of fluency for individual and pair essays. Considering the alpha level $\mathrm{p}<.05$, there was no significant difference between the fluency of essays written by individuals and that of essays written by pairs in the last session.

Based on the results drawn from the study, there was no significant difference between the mean of fluency in individual and pair essays written in the first session of writing phase; therefore, null hypothesis $H_{01}$ was not rejected in this regard. Although there was a significant difference between the average number of T-units and clauses of individual and pair essays in the last session of writing phase, the difference between the mean of fluency as a single measure was not significant. Thus, null hypothesis $H_{011}$ was again not rejected for the texts written in the last session.

\section{B. Null Hypothesis/H $\mathbf{H}_{02}$}

$\boldsymbol{H}_{02}$ : Pair work does not influence the degree of improvement in fluency of the writing tasks. To this point, the fluency of the scripts produced by individuals and pairs in the first session of the writing phase and in the last session has been analyzed separately. At this stage, it is noteworthy to investigate what is the difference in percentage. To put it differently, the aim of posing the last research question was to find out the effect of pair work on the degree of improvement in fluency of the writing task. For this purpose, the essays written by individuals in the first session of the writing phase have been compared with those produced by them in the last session in terms of mean for each measure. The same was done for the scripts written by the pairs in the first and last session of the writing phase. What has been said so far can be better illustrated in the following tables. Each table is further followed by some figures which display the degree of improvement in percentage. It should be kept in mind that the results will be presented within two tables first of which referring to the sub-measures of fluency and the second one to the fluency as a single unit.

In Table IX, the essays written in the first and last session of the writing phase are compared with regard to the average number of words, T-units, and clauses per text. As can be seen, the means for all measures in the last essays produced by all learners, either individuals or pairs, were higher than those in the first essays. 
TABLE IX.

\begin{tabular}{|c|c|c|c|}
\hline & Groups & First Writing Mean & Last Writing Mean \\
\hline \multirow[t]{2}{*}{ Words } & Individual essays & 257.1 & 294.23 \\
\hline & Pair essays & 249.9 & 289.47 \\
\hline \multirow[t]{2}{*}{ T-units } & Individual essays & 16.53 & 20.5 \\
\hline & Pair essays & 17.1 & 22 \\
\hline \multirow[t]{2}{*}{ Clauses } & Individual essays & 24 & 31 \\
\hline & Pair essays & 24.7 & 37.9 \\
\hline
\end{tabular}

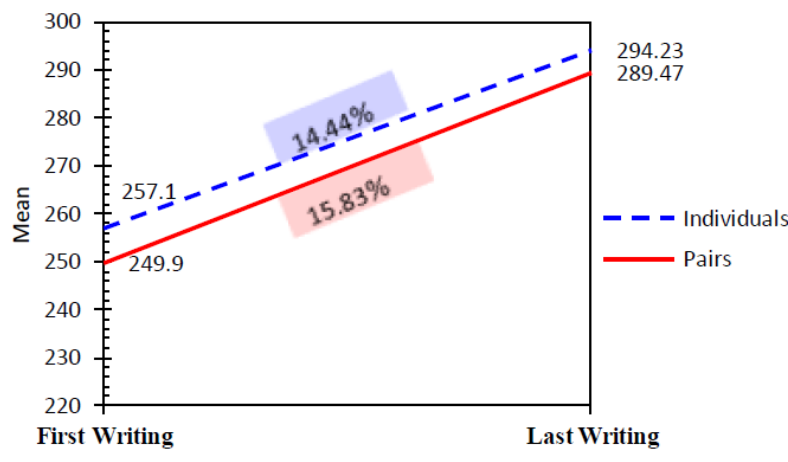

Figure 1. Degree of Improvement in Word Use

The above figure shows that there was a rising order in the average number of words per text for both groups. In comparison with pairs, individuals used more words in both sessions. However, the difference between two groups for the rates of improvement in the use of words in percentage was not noticeable.

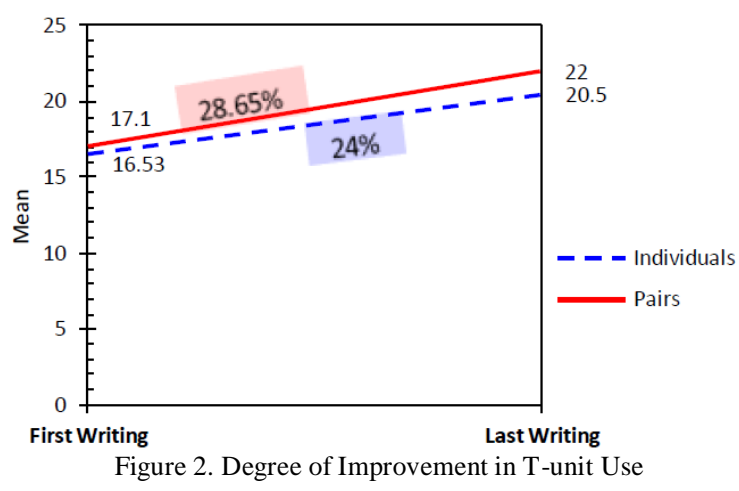

Figure 2 is the illustration of using T-units in the first and the last writings produced by individuals and pairs. The average number of T-units was more in the last writing which shows an increasing trend in the chart. Considering the percentage of improvement, the pairs had improved about $4.5 \%$ more than the individuals with regard to the use of $\mathrm{T}$ units.

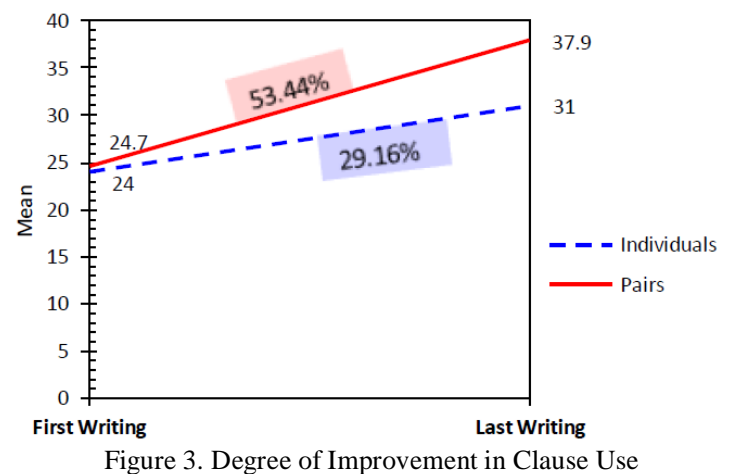

According to Figure 3, the average number of clauses per text for the first essays written by pairs and individuals was almost the same. Although progress can be seen in both groups, the degree of improvement in the use of clauses was higher for pairs than individuals. Pairs had progressed about $24 \%$ more than individuals in this regard. This difference in percentage was significant. 
TABLE X.

MEAN VALUES OF TEXT FLUENCY FOR THE FIRST AND LAST WRITING TASKS

\begin{tabular}{|ll|l|l|}
\hline & Groups & First Writing Mean & Last Writing Mean \\
\hline Fluency & Individual essays & 102.1005 & $\mathbf{1 1 9 . 5 2 3 3}$ \\
& Pair essays & 100.0188 & $\mathbf{1 2 0 . 3 1 2 3}$ \\
\hline
\end{tabular}

Table X expresses the mean of fluency as a whole in the essays written by individuals and pairs during the first and the last sessions.

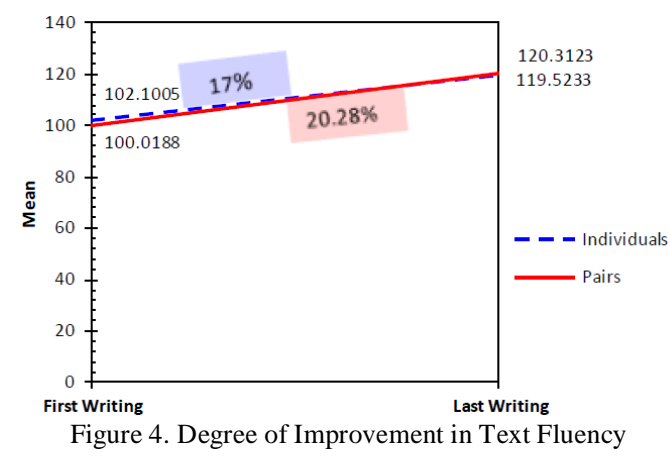

As it can be seen in Figure 4, the texts produced in the last session are more fluent than those produced in the first session. However, the percentage of improvement between the two groups was not significant.

\section{DISCUSSION AND CONCLUSION}

Referring to the first question of this study about the difference between scripts produced by individuals versus pairs in terms of fluency, Table II and IV show that there is no difference between the fluency of the individual essays and pair essays $(p=0.473$ ) in the first session of the writing phase. (It is here worthy to mention that for the null hypothesis to be rejected, the observed value of $p$ must be smaller than the significance level of .05 $[p<.05]$. If the observed $p$ value is equal or greater than the significance level of .05 , the null hypothesis cannot be rejected.) Since the $p$-value for fluency of the texts written in the first session is 0.473 and it is greater than .05 , the null hypothesis cannot be rejected in this regard. This is supported by the study of Wigglesworth and Storch (2009) in an assessment context according to which performance for both groups were similar across all measures of fluency. Therefore, working collaboratively for only one session has not affected the fluency of the texts. Table VI and VIII reveals the results of all sub-measures of fluency and fluency itself respectively for the essays written in the last session. Even after practicing for more six sessions, pairs have not produced more fluent texts than individuals $(p=0.705)$. Although the fluency of the texts for both groups is similar based on Table VIII, Table VI shows that pairs have used more T-units $(p=0.32)$ and clauses $(p$ $=0.000)$ than individuals as a result of practicing in pairs for seven sessions. Generally speaking, collaboration in pair writing task does not lead to producing more fluent texts in comparison with individual writing.

According to the second question put forward in this study, one can see the effect of pair work on the degree of improvement in fluency of the writing tasks. Figures 1, 2, and 3 illustrate the rate of improvement for the three submeasures of fluency including words, T-units, and clauses. As it can be conveyed in Figure 1, each group has developed a growth in number of used words; however, the difference between the degrees of improvement for the average number of words used per text is not noticeable (14.44\% in individual essays and $15.83 \%$ in pair essays). This figure also shows that collaboration not only has not helped the pairs to use more words per text but also slowed down their writing pace. According to Figure 2, there is a rising tendency in the use of T-units by individuals (24\%) and pairs $(28.65 \%)$. Considering the percentage of T-unit improvement, collaboration has provided the pairs with the opportunity to progress about $4.5 \%$ more than individuals. One of the most appreciable results gained from the data in this study is the effect of collaboration in pair work on using more clauses per text (Figure 3). Individuals have developed $29.16 \%$ while pairs have developed $53.44 \%$ whose difference is about $24 \%$. We can conclude that the degree of improvement in the use of clauses for individuals is about half as much as pairs. Regarding the sub-measures of fluency, collaboration leads to learners improvement in T-units and clauses but not words. Figure 4 shows that fluency of individual texts has developed $17 \%$ whereas fluency of pair texts has developed about $20 \%$.

In summary, this study was designed to investigate the effect of pair working on the fluency of scripts written by Iranian intermediate learners. The findings imply that although there was rising progress in the use of $\mathrm{T}$-units and clauses by pairs, the fluency of the written texts was not significant enough in comparison to the fluency of essays produced by individuals.

\section{APPENDIX A: Number of OCCURRENCE OF EACH MEASURE IN INDIVIDUAL ESSAYS FOR THE FIRST SESSION OF THE} WRITING PHASE 


\begin{tabular}{|l|l|l|l|}
\hline Individuats & Words & T-units & Clauses \\
\hline 1 & $\mathbf{2 9 5}$ & $\mathbf{2 3}$ & $\mathbf{2 8}$ \\
\hline 2 & $\mathbf{2 8 9}$ & $\mathbf{2 3}$ & $\mathbf{2 9}$ \\
\hline 3 & $\mathbf{2 8 7}$ & $\mathbf{2 2}$ & $\mathbf{2 9}$ \\
\hline 4 & $\mathbf{2 8 6}$ & $\mathbf{2 2}$ & $\mathbf{3 0}$ \\
\hline 5 & $\mathbf{2 8 5}$ & $\mathbf{2 1}$ & $\mathbf{2 8}$ \\
\hline 6 & $\mathbf{2 8 4}$ & $\mathbf{2 1}$ & $\mathbf{2 7}$ \\
\hline 7 & $\mathbf{2 8 4}$ & $\mathbf{2 0}$ & $\mathbf{2 7}$ \\
\hline 8 & $\mathbf{2 8 1}$ & $\mathbf{2 0}$ & $\mathbf{2 6}$ \\
\hline 9 & $\mathbf{2 8 1}$ & $\mathbf{1 9}$ & $\mathbf{2 7}$ \\
\hline 10 & $\mathbf{2 7 9}$ & $\mathbf{1 9}$ & $\mathbf{2 6}$ \\
\hline 11 & $\mathbf{2 7 8}$ & $\mathbf{1 8}$ & $\mathbf{2 5}$ \\
\hline 12 & $\mathbf{2 7 4}$ & $\mathbf{1 8}$ & $\mathbf{2 4}$ \\
\hline 13 & $\mathbf{2 7 3}$ & $\mathbf{1 7}$ & $\mathbf{2 5}$ \\
\hline 14 & $\mathbf{2 7 2}$ & $\mathbf{1 7}$ & $\mathbf{2 4}$ \\
\hline 15 & $\mathbf{2 7 1}$ & $\mathbf{1 6}$ & $\mathbf{2 4}$ \\
\hline
\end{tabular}

\begin{tabular}{|l|l|l|l|}
\hline Individuats & Words & T-units & Clauses \\
\hline 16 & $\mathbf{2 6 4}$ & $\mathbf{1 6}$ & $\mathbf{2 2}$ \\
\hline 17 & $\mathbf{2 5 3}$ & $\mathbf{1 6}$ & $\mathbf{2 3}$ \\
\hline 18 & $\mathbf{2 5 1}$ & $\mathbf{1 5}$ & $\mathbf{2 3}$ \\
\hline 19 & $\mathbf{2 4 5}$ & $\mathbf{1 5}$ & $\mathbf{2 3}$ \\
\hline 20 & $\mathbf{2 3 9}$ & $\mathbf{1 5}$ & $\mathbf{2 1}$ \\
\hline 21 & $\mathbf{2 3 5}$ & $\mathbf{1 4}$ & $\mathbf{2 4}$ \\
\hline 22 & $\mathbf{2 3 3}$ & $\mathbf{1 4}$ & $\mathbf{2 2}$ \\
\hline 23 & $\mathbf{2 3 1}$ & $\mathbf{1 3}$ & $\mathbf{2 2}$ \\
\hline 24 & $\mathbf{2 2 8}$ & $\mathbf{1 3}$ & $\mathbf{2 3}$ \\
\hline 25 & $\mathbf{2 2 7}$ & $\mathbf{1 3}$ & $\mathbf{2 1}$ \\
\hline 26 & $\mathbf{2 2 4}$ & $\mathbf{1 2}$ & $\mathbf{2 0}$ \\
\hline 27 & $\mathbf{2 2 0}$ & $\mathbf{1 2}$ & $\mathbf{2 0}$ \\
\hline 28 & $\mathbf{2 1 9}$ & $\mathbf{1 1}$ & $\mathbf{2 0}$ \\
\hline 29 & $\mathbf{2 1 5}$ & $\mathbf{1 1}$ & $\mathbf{1 9}$ \\
\hline 30 & $\mathbf{2 1 0}$ & $\mathbf{1 0}$ & $\mathbf{1 8}$ \\
\hline
\end{tabular}

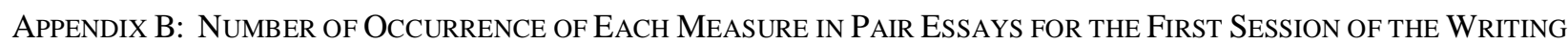
PHASE

\begin{tabular}{|l|l|l|l|}
\hline Pairs & Words & T-units & Clauses \\
\hline 1 & $\mathbf{2 8 7}$ & $\mathbf{2 3}$ & $\mathbf{3 0}$ \\
\hline 2 & $\mathbf{2 8 3}$ & $\mathbf{2 1}$ & $\mathbf{3 0}$ \\
\hline 3 & $\mathbf{2 7 9}$ & $\mathbf{2 1}$ & $\mathbf{2 9}$ \\
\hline 4 & $\mathbf{2 7 8}$ & $\mathbf{2 0}$ & $\mathbf{2 9}$ \\
\hline 5 & $\mathbf{2 7 5}$ & $\mathbf{2 0}$ & $\mathbf{2 8}$ \\
\hline 6 & $\mathbf{2 7 4}$ & $\mathbf{2 0}$ & $\mathbf{2 7}$ \\
\hline 7 & $\mathbf{2 7 1}$ & $\mathbf{2 0}$ & $\mathbf{2 6}$ \\
\hline 8 & $\mathbf{2 7 0}$ & $\mathbf{1 9}$ & $\mathbf{2 8}$ \\
\hline 9 & $\mathbf{2 6 9}$ & $\mathbf{1 9}$ & $\mathbf{2 7}$ \\
\hline 10 & $\mathbf{2 6 7}$ & $\mathbf{1 9}$ & $\mathbf{2 7}$ \\
\hline 11 & $\mathbf{2 6 5}$ & $\mathbf{1 9}$ & $\mathbf{2 6}$ \\
\hline 12 & $\mathbf{2 6 4}$ & $\mathbf{1 9}$ & $\mathbf{2 5}$ \\
\hline 13 & $\mathbf{2 6 3}$ & $\mathbf{1 8}$ & $\mathbf{2 8}$ \\
\hline 14 & $\mathbf{2 6 1}$ & $\mathbf{1 8}$ & $\mathbf{2 6}$ \\
\hline 15 & $\mathbf{2 5 8}$ & $\mathbf{1 8}$ & $\mathbf{2 5}$ \\
\hline
\end{tabular}

\begin{tabular}{|l|l|l|l|}
\hline Pairs & Words & T-units & Clauses \\
\hline 16 & $\mathbf{2 5 5}$ & $\mathbf{1 8}$ & $\mathbf{2 4}$ \\
\hline 17 & $\mathbf{2 5 4}$ & $\mathbf{1 7}$ & $\mathbf{2 5}$ \\
\hline 18 & $\mathbf{2 4 9}$ & $\mathbf{1 7}$ & $\mathbf{2 4}$ \\
\hline 19 & $\mathbf{2 4 8}$ & $\mathbf{1 6}$ & $\mathbf{2 4}$ \\
\hline 20 & $\mathbf{2 3 7}$ & $\mathbf{1 6}$ & $\mathbf{2 3}$ \\
\hline 21 & $\mathbf{2 3 1}$ & $\mathbf{1 6}$ & $\mathbf{2 1}$ \\
\hline 22 & $\mathbf{2 2 8}$ & $\mathbf{1 5}$ & $\mathbf{2 3}$ \\
\hline 23 & $\mathbf{2 2 5}$ & $\mathbf{1 5}$ & $\mathbf{2 2}$ \\
\hline 24 & $\mathbf{2 2 4}$ & $\mathbf{1 4}$ & $\mathbf{2 2}$ \\
\hline 25 & $\mathbf{2 2 1}$ & $\mathbf{1 4}$ & $\mathbf{2 3}$ \\
\hline 26 & $\mathbf{2 2 0}$ & $\mathbf{1 3}$ & $\mathbf{2 1}$ \\
\hline 27 & $\mathbf{2 1 8}$ & $\mathbf{1 3}$ & $\mathbf{2 0}$ \\
\hline 28 & $\mathbf{2 1 2}$ & $\mathbf{1 2}$ & $\mathbf{2 0}$ \\
\hline 29 & $\mathbf{2 0 7}$ & $\mathbf{1 2}$ & $\mathbf{1 9}$ \\
\hline 30 & $\mathbf{2 0 4}$ & $\mathbf{1 1}$ & $\mathbf{1 9}$ \\
\hline
\end{tabular}

APPENDIX C: Number of OCCURRENCE OF EACH MEASURE IN INDIVIDUAL ESSAYS FOR the LAST SESSION OF THE WRITING PHASE

\begin{tabular}{|l|l|l|l|}
\hline Individuats & Words & T-units & Clauses \\
\hline 31 & $\mathbf{3 3 5}$ & $\mathbf{2 8}$ & $\mathbf{3 6}$ \\
\hline 32 & $\mathbf{3 3 4}$ & $\mathbf{2 5}$ & $\mathbf{3 5}$ \\
\hline 33 & $\mathbf{3 3 1}$ & $\mathbf{2 3}$ & $\mathbf{3 5}$ \\
\hline 34 & $\mathbf{3 2 9}$ & $\mathbf{2 3}$ & $\mathbf{3 3}$ \\
\hline 35 & $\mathbf{3 2 7}$ & $\mathbf{2 3}$ & $\mathbf{3 4}$ \\
\hline 36 & $\mathbf{3 2 5}$ & $\mathbf{2 2}$ & $\mathbf{3 2}$ \\
\hline 37 & $\mathbf{3 2 2}$ & $\mathbf{2 2}$ & $\mathbf{3 0}$ \\
\hline 38 & $\mathbf{3 2 1}$ & $\mathbf{2 2}$ & $\mathbf{3 4}$ \\
\hline 39 & $\mathbf{3 1 9}$ & $\mathbf{2 1}$ & $\mathbf{3 4}$ \\
\hline 40 & $\mathbf{3 1 8}$ & $\mathbf{2 1}$ & $\mathbf{3 5}$ \\
\hline 41 & $\mathbf{3 1 6}$ & $\mathbf{2 1}$ & $\mathbf{3 3}$ \\
\hline 42 & $\mathbf{3 1 4}$ & $\mathbf{2 1}$ & $\mathbf{3 0}$ \\
\hline 43 & $\mathbf{3 1 3}$ & $\mathbf{2 1}$ & $\mathbf{2 9}$ \\
\hline 44 & $\mathbf{3 1 1}$ & $\mathbf{2 0}$ & $\mathbf{3 3}$ \\
\hline 45 & $\mathbf{3 0 7}$ & $\mathbf{2 0}$ & $\mathbf{3 4}$ \\
\hline
\end{tabular}

\begin{tabular}{|l|l|l|l|}
\hline Individuats & Words & T-units & Clauses \\
\hline 46 & $\mathbf{2 9 9}$ & $\mathbf{2 0}$ & $\mathbf{3 2}$ \\
\hline 47 & $\mathbf{2 9 4}$ & $\mathbf{2 0}$ & $\mathbf{2 9}$ \\
\hline 48 & $\mathbf{2 8 8}$ & $\mathbf{2 0}$ & $\mathbf{3 1}$ \\
\hline 49 & $\mathbf{2 8 3}$ & $\mathbf{2 0}$ & $\mathbf{3 3}$ \\
\hline 50 & $\mathbf{2 8 1}$ & $\mathbf{1 9}$ & $\mathbf{3 4}$ \\
\hline 51 & $\mathbf{2 7 8}$ & $\mathbf{1 9}$ & $\mathbf{3 3}$ \\
\hline 52 & $\mathbf{2 7 6}$ & $\mathbf{1 9}$ & $\mathbf{2 9}$ \\
\hline 53 & $\mathbf{2 6 5}$ & $\mathbf{1 9}$ & $\mathbf{3 2}$ \\
\hline 54 & $\mathbf{2 6 5}$ & $\mathbf{1 9}$ & $\mathbf{2 8}$ \\
\hline 55 & $\mathbf{2 6 4}$ & $\mathbf{1 9}$ & $\mathbf{2 7}$ \\
\hline 56 & $\mathbf{2 5 9}$ & $\mathbf{1 8}$ & $\mathbf{2 6}$ \\
\hline 57 & $\mathbf{2 4 7}$ & $\mathbf{1 8}$ & $\mathbf{2 4}$ \\
\hline 58 & $\mathbf{2 4 5}$ & $\mathbf{1 8}$ & $\mathbf{2 5}$ \\
\hline 59 & $\mathbf{2 4 1}$ & $\mathbf{1 7}$ & $\mathbf{2 6}$ \\
\hline 60 & $\mathbf{2 2 0}$ & $\mathbf{1 7}$ & $\mathbf{2 4}$ \\
\hline
\end{tabular}

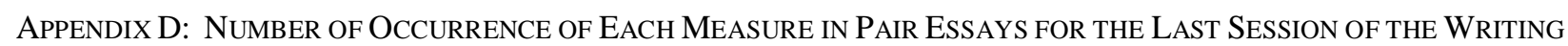
PHASE 


\begin{tabular}{|l|l|l|l|}
\hline Pairs & Words & T-units & Clauses \\
\hline 31 & 341 & 29 & 45 \\
\hline 32 & 332 & 27 & 42 \\
\hline 33 & 329 & 26 & 43 \\
\hline 34 & 328 & 25 & 41 \\
\hline 35 & 325 & 24 & 42 \\
\hline 36 & 324 & 24 & 43 \\
\hline 37 & 322 & 24 & 38 \\
\hline 38 & 319 & 24 & 41 \\
\hline 39 & 315 & 24 & 35 \\
\hline 40 & 312 & 23 & 40 \\
\hline 41 & 311 & 23 & 38 \\
\hline 42 & 309 & 23 & 40 \\
\hline 43 & 305 & 23 & 37 \\
\hline 44 & 299 & 22 & 41 \\
\hline 45 & 289 & 22 & 40 \\
\hline & & & \\
\hline
\end{tabular}

\begin{tabular}{|l|l|l|l|}
\hline Pairs & Words & T-units & Clauses \\
\hline 46 & 288 & 22 & 39 \\
\hline 47 & 280 & 22 & 37 \\
\hline 48 & 270 & 21 & 36 \\
\hline 49 & 271 & 21 & 36 \\
\hline 50 & 266 & 21 & 34 \\
\hline 51 & 264 & 21 & 35 \\
\hline 52 & 262 & 20 & 35 \\
\hline 53 & 261 & 20 & 35 \\
\hline 54 & 259 & 20 & 40 \\
\hline 55 & 258 & 20 & 34 \\
\hline 56 & 255 & 19 & 36 \\
\hline 57 & 252 & 19 & 35 \\
\hline 58 & 249 & 19 & 34 \\
\hline 59 & 245 & 17 & 34 \\
\hline 60 & 244 & 15 & 31 \\
\hline & & &
\end{tabular}

\section{REFERENCES}

[1] Al-Jarf, R. S. (2007). Online instruction and creative writing by Saudi EFL freshman students. Asian EFL Journal: King Saud University, Riyadh, Saudi Arabia. Teaching Articles 22 (3). http://www.asian-efl-journal.com/pta_Aug_07_rajl.php (accessed 10/1/2011).

[2] Boud, D. (2001). Introduction: Making the move to peer learning. In D. Boud, R. Cohen \& J. Sampson (Eds.), Peer learning in higher education: Learning from \& with each other (pp. 1-17). London: Kogan Page Ltd.

[3] Cheek, D. W. (1992). Thinking constructively about science: Technology and society education. Albany, NY: State University of New York Press.

[4] Cooper, M. M. (1986). The Ecology of Writing. College English, 48, 364-75.

[5] DiCamilla, F. J. \& M. Anton (1997). Repetition in the collaborative discourse of L2 learners: A Vygotskian perspective. Canadian Modern Language Review, 53(4), 609-633.

[6] Dillenbourg, P. (1999). Collaborative learning: Cognitive and computational approaches. Advances in Learning and Instruction Series. New York, NY: Elsevier Science, Inc.

[7] Doughty, C. \& M. H. Long (Eds.). (2003). The handbook of second language acquisition. Malden, MA: Blackwell Publishing Ltd.

[8] Foster, J. (2008). Effective writing skills for public relations. Kogan Page Ltd.

[9] Gass, S. M. (1997). Input, interaction, and second language learner. Mahwah, NJ: Lawrence Erlbaum Associates.

[10] Gass, S. M. \& A. Mackey (2006). Input, interaction, and output: An overview. AILA Review, 19, 3-17.

[11] Gass, S. M. \& L. Selinker (2008). Second language acquisition: An introductory course (3rd ed.). New York, London: Routledge.

[12] Hawkey, R. (2004). A modular approach to testing English language skills: The development of the Certificates in English Language Skills (CELS) examinations. Cambridge: UCLES, Cambridge University Press.

[13] Hayes, J. R. \& L. S. Flower (1986). Writing research and the writer. American Psychologist, 41 (10), 1106-1113.

[14] Hinkel, E. \& S. Fotos (Eds.). (2002). New perspectives on grammar teaching in second language classrooms. Mahwah, NJ: Lawrence Erlbaum Associates.

[15] Hirose, K. (2009). Cooperative learning in English writing instruction through peer feedback. Japan, Nagakute City: Aichi Prefectural University.

[16] Hong, F. (2006). Students' perceptions of peer response activity in English writing instruction. Teaching English in China, 29(4), 48-52.

[17] Hudelson, S. (1988). Children's writing in ESL. ERIC Digest. ERIC Clearinghouse on Assessment and Evaluation.

[18] Hyland, K. (2003). Second language writing. New York: Cambridge University Press.

[19] Jacobs, G. M., A. Curtis, G. Braine \& S. Y. Huang (1998). Feedback on students writing: Taking the middle path. Journal of Second Language Writing, 7, 307-317.

[20] Jiao, L. Y. (2007, May). Application of cooperative learning in teaching college English writing. US-China Foreign Language (ISSN 1539-8080), USA, 5(5, Serial No.44). http://www.articlesbase.com/languages-articles/teaching-writing-through-peerfeedback-2731309.html (accessed 11/1/2011).

[21] Johnson, D. W. \& R. T. Johnson (1994). Learning together and alone: Cooperative, competitive, and individualistic learning (4th ed.). Boston: Allyn \& Bacon.

[22] Kamimura, T. (2006). Effects of peer feedback on EFL student writers at different levels of English proficiency: A Japanese context. TESL Canada Journal, 23(2), 12-39.

[23] Kumpulainen, K. \& D. Wray (Eds.). (2002). Classroom interaction and social learning: From theory to practice. London: Routledge Falmer.

[24] Kurt, G. \& D. Atay (2007). The effects of peer feedback on the writing anxiety of prospective Turkish teachers of EFL. Journal of Theory and Practice in Education, 3(1), 12-23.

[25] Lantolf, J. P. (2000). Second language learning as a mediated process. Language teaching: The international abstracting journal for language teachers and applied linguists, 33, 79-96.

[26] Lee, N. S. (2009). Written peer feedback by EFL students: Praise, criticism, and suggestion. Komaba Journal of English Education, 1, 129-139. 
[27] Macaro, E. (1997). Target language, collaborative learning, and autonomy. Clevedon, Avon: Multilingual Matters.

[28] Matsuda, P. K. (2003). Second language writing in the twentieth century: A situated historical perspective. In B. Kroll (Ed.), Exploring the dynamics of second language writing (pp. 15-34). New York: Cambridge University Press.

[29] Morris, C. (2008, January). Lev Semyonovich Vygotsky's Zone of Proximal Development. Retrieved November 15, 2010, from Success is Thinking and Working Smarter not Harder Web site: http://www.igs.net/ cmorris/zpd.html.

[30] Nunan, D. (1989). Designing tasks for the communicative classroom. Cambridge: Cambridge University Press.

[31] Ohta, A. S. (2001). Peer integrative tasks and assisted performance in classroom language learning. In A. S. Ohta (Ed.), Second language acquisition process in the classroom: Learning Japanese (pp.73-128). Mahwah, NJ: Lawrence Erlbaum.

[32] Oliver, R. (2002). The patterns of negotiation for meaning in child interactions. Modern Language Journal, 86, 97-111.

[33] Pica, T., L. Holliday, N. Lewis \& L. Morgenthaler (1989). Comprehensible output as an outcome of linguistic demands on the learner. Studies in Second Language Acquisition, 11(1), 63-90.

[34] Pinter, A. (2005). Task repetition with 10-year-old children. In C. Edwards \& J. Willis (Eds.), Teachers exploring tasks in English language teaching (pp. 113-126). Basingstoke: Palgrave Macmillan.

[35] Pinter, A. (2007). Benefits of peer-peer interaction: 10-year-old children practicing with a communication task. Language Teaching Research, 11(2), 1-19.

[36] Raimes, A. (1987). Why write? From purpose to pedagogy. English Teaching Forum. 25(4), 36-41.

[37] Rollinson, P. (2005). Using peer feedback in the ESL writing class. ELT Journal, 59(1), 23-30.

[38] Roschelle, J. \& S. D. Teasley (1995). The construction of shared knowledge in collaborative problem solving. In C. E. O'Malley (Ed.), Computer-supported collaborative learning (pp. 69-197). Berlin: Springer-Verlag.

[39] Sharples, M., J. Goodlet \& L. Pymberton (1989). Developing a writer's assistant. In N. Williams \& P. Holt (Eds.), Computers and writing. Norwood: N. J. Ablex.

[40] Spear, K. I. (1988). Sharing writing: Peer response groups in English classes. NH: Boynton/Cook Publisher.

[41] Storch, N. (2005). Collaborative writing: Product, process, and students' reflections. Journal of Second Language Writing, 14(3), 153-173.

[42] Storch, N. \& G. Wigglesworth (2007). Writing tasks and the effects of collaboration. In M. Pillar (Ed.), Investigating tasks in formal language settings (pp. 157-177). Clevedon: Multilingual Matters.

[43] Sullivan, P. N. (2000). Playfulness as mediation in communicative language teaching in a Vietnamese classroom. In J. P. Lantolf (Ed.), Sociocultural theory and second language learning (pp. 115-132). Oxford: Oxford University Press.

[44] Swain, M. (2005). The output hypothesis: Theory and research. In E. Hinkel (Ed.), Handbook of research in second language teaching and learning (pp. 471-484). Mahwah, NJ: Erlbaum.

[45] Swain, M. \& S. Lapkin (1998). Interaction and second language learning: Two adolescent French immersion students working together. Modern Language Journal, 82(3), 320-337.

[46] Topping, K. J. (2001). Peer assisted learning: A practical guide for teachers. Cambridge, MA: Brookline Books.

[47] Tsai, S. (1998). The effects of cooperative learning on teaching English as a foreign language to senior high school students. Master's Thesis. National Kaohsiung Normal University.

[48] Tsui, A. (1995). Introducing classroom interaction. London: Penguin.

[49] Tynjala, P., L. Mason \& K. Lonka (Eds.). (2001). Writing as a learning tool: Integrating theory and practice. Dordrecht, The Netherlands: Kluwer Academic.

[50] Vygotsky, L. S. (1978). Mind in society: The development of higher psychological processes. Cambridge, MA: Harvard University Press.

[51] Weigle, S. C. (2002). Assessing writing, Cambridge: Cambridge University Press.

[52] Wigglesworth, G. \& N. Storch (2009). Pairs versus individual writing: Effects on fluency, complexity, and accuracy. Language Testing, 26(3), 445-466.

[53] Williams, J. (1957). Teaching writing in second and foreign language classroom. London: McGraw Hill.

[54] Willis, J. (1996). A framework for task-based learning. London: Longman.

[55] Yager, R. (1991). The constructivist learning model, towards real reform in science education. The Science Teacher, 58(6), 5257.

[56] Zeng, D. (2005). The process-oriented approach to ESL/EFL writing instruction and research. Teaching English in China, 28(5), 66-77.

[57] Zeng, Y. (2006). Peer feedback in college SLW classroom. Sino-US English Teaching, ISSN 1539-8072, 3(3, Serial No.27). USA. eprints.utp.edu.my/7347/1/mlearn2011_submission_64.pdf (accessed 13/1/2011).

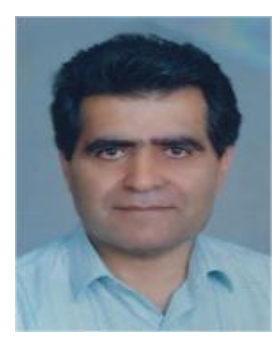

Reza Biria, born in Isfahan, Iran, obtained his Ph.D. in teaching English as a Foreign Language from the University of Isfahan in 2001. He is an applied linguistics assistant professor working at Khorasgan Azad University, Isfahan, Iran. Dr. Biria has published papers in national and international conferences. His research interests include teaching English as a second and foreign language and ESP. 


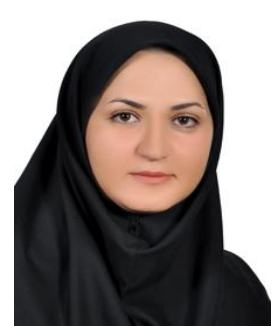

Sahar Jafari, born in Tehran, Iran, received her B.A in English Language Translation at University of Sheikh Bahaee, Isfahan, Iran in 2007. She has got her MA in Teaching English as a Foreign Language from Islamic Azad University of Khorasgan, Isfahan, Iran. She has been teaching English since 2005. Her main research interests lie in writing and listening strategies in language teaching. 